\title{
Novo Regime Fiscal e a constitucionalização do contingenciamento das despesas primárias obrigatórias
}

\author{
| 1 Élida Graziane Pinto | \\ ${ }^{1}$ Ministério Público de Contas do Estado de São Paulo. São Paulo-SP, Brasil (egraziane@tce.sp.gov.br).

A Proposta de Emenda Constitucional no 241/2016 (tal como tramitou na Câmara) ou, mais recentemente, PEC no 55/2016 (como foi designada no Senado) pretende inserir no Ato das Disposiçôes Constitucionais Transitórias um "Novo Regime Fiscal", com a finalidade de limitar globalmente as despesas primárias pelo quanto for aplicado em 2016, sendo assegurada tão somente a correção monetária. Sua concepção é a de uma rota dita temporária (vintenária) e paralela (exceção à regra geral) em relação ao texto permanente da Constituição de 1988, para o enfrentamento da crise orçamentário-financeira do país. O risco, contudo, é que uma regra de exceção - que se pretende válida por 20 (vinte) anos - tenda paulatinamente a se tornar a nova regra permanente...

A finalidade é limitar empenhos e movimentação financeira das despesas primárias da União, independentemente do comportamento da receita federal e da evolução da realidade econômica do país, de modo a constitucionalizar a busca - no médio prazo - de resultados primários positivos, ainda que isso implique deficit de eficácia dos direitos fundamentais postergados ou inadimplidos. $\mathrm{O}$ processo de elaboração e execução dos orçamentos federais passará a ter como eixo estruturante a fixação de limite máximo para a despesa primária total de cada Poder ou órgão autônomo, a partir de regra geral de limitação de quaisquer gastos excedentes ao patamar do quanto houver sido pago em 2016 e corrigido monetariamente pela inflação verificada no ano anterior, conforme o Índice de Preços ao Consumidor Amplo (IPCA). 
Alheias ao teto, contudo, seguirão as despesas financeiras, já que, até o presente momento, a União se ressente da falta de limite para sua dívida pública, nos moldes já propugnados na Constituição Federal desde 1988. Em igual medida, não há qualquer previsão de ajuste referido ao comportamento das receitas no "Novo Regime Fiscal", onde se destaca, sobretudo, a omissão quanto à revisão das renúncias fiscais concedidas ao arrepio da Lei de Responsabilidade Fiscal.

Vale lembrar que, no ordenamento jurídico brasileiro, a ideia de teto fiscal para as despesas públicas primárias não é nova. A bem da verdade, há que se reconhecer a fronteira pragmática do total das receitas arrecadadas para fins de delimitação da autorização de gastos primários na lei orçamentária anual (art. 167, I da CR/88) e mesmo para fins de contingenciamento durante a execução de tal lei no decorrer do exercício financeiro (art. 9o da LRF).

Os tetos fiscais já vigentes são, pois, tanto o limite máximo da autorização legal de despesa (dotação), quanto o limite de empenho e/ou movimentação financeira (contingenciamento). Anualmente, já se administra no Brasil o limite de gastos na fronteira das receitas arrecadadas, em consonância com as metas fiscais previstas também a cada exercício na lei de diretrizes orçamentárias. As diferenças desses limites em face do teto fiscal previsto na PEC do "Novo Regime Fiscal" residem em três grandes variáveis:

1) tempo de duração (anual para os primeiros e vintenário para o limite da PEC);

2) incidência apenas sobre despesas discricionárias nos tetos fiscais já vigentes e incidência sobre todas as despesas primárias para o limite em tramitação, no que se dá sua maior controvérsia jurídica, haja vista a mitigação parcial do regime jurídico das despesas primárias obrigatórias; e por fim,

3) proporcionalidade entre receitas e despesas, que rege a fronteira máxima da dotação orçamentária e mesmo do contingenciamento, vez que a possibilidade de realização da despesa depende, sobretudo, do ingresso da receita e, por conseguinte, do cumprimento das metas fiscais. $\mathrm{Na}$ PEC do "Novo Regime Fiscal", todavia, tal proporcionalidade cai por terra e o teto fiscal se autonomiza em face da execução orçamentária em sua dinâmica real.

A PEC no 241/2016 (tal como tramitou na Câmara) ou também PEC n ${ }^{\circ}$ 55/2016 (em sua nova designação no Senado) parte do pressuposto de que a 
fixação das dotações na lei de orçamento anual (LOA), bem como a definição das metas fiscais anualmente na lei de diretrizes orçamentárias (LDO) e sua persecução por meio do contingenciamento já não são suficientes para lidar com o risco de insustentabilidade da relação entre dívida pública e produto interno bruto. A busca de alternativa mais drástica decorreria, em tese, da fragilidade de tais comportas orçamentárias ordinárias. Seria, pois, necessária uma comporta extraordinária e extremamente rígida para conter o avanço das despesas governamentais obrigatórias.

O regime ainda vigente reside na leitura conjugada dos arts. $4^{\circ}$ e $9^{\circ}$ da Lei Complementar no 101/2000, de modo que o risco de descumprimento das metas fiscais enseja a adoção vinculante do contingenciamento (limitação de empenho e de movimentação financeira), o qual, por seu turno, explicita o limite máximo de gastos do Poder Público conforme o fluxo dinâmico da execução orçamentária.

O teto da PEC do "Novo Regime Fiscal" (gasto pago em 2016, apenas corrigido pela inflação) tem, historicamente, no modelo do contingenciamento "preventivo", um indiscutível precedente. $\mathrm{O}$ ato de impor limitação de empenhos e de movimentação financeira antes mesmo do risco de frustração das metas fiscais fora usado entre 2002 a 2008, quando o Brasil conseguia realizar superavit primários sensivelmente superiores (por vezes, acima de 3\% do PIB) às metas das correspondentes leis de diretrizes orçamentárias.

Com o acirramento da crise econômica mundial a partir de 2009 e, em especial no Brasil, a partir de 2014, o mecanismo de ajuste entre receitas e despesas primárias discricionárias, que era alcançado anualmente por meio dos superavit primários, teria perdido, em tese, sua eficácia. Daí por que o foco da ideia de ajuste passou a mirar a necessidade de constranger o comportamento progressivo das despesas primárias obrigatórias.

Eis a base fática que, direta ou indiretamente, deu ensejo ao advento da PEC no $241 /$ PEC no 55/2016. O teto global para despesas primárias ali concebido visa extremar a concepção do modus operandi já existente de metas fiscais anualmente fixadas na lei de diretrizes orçamentárias (conforme prevê o art. $4^{\circ}$ da LRF), onde a contenção de despesas autorizadas em face das receitas estimadas (contingenciamento) objetivava assegurar o alcance daquelas metas, com destaque para a meta de resultado primário.

Com a PEC do Teto, o regime fiscal de formação de saldos positivos para o pagamento das despesas financeiras passará a ser um comando constitucional 
abstrato (regra de crescimento real nulo para o conjunto das despesas primárias), com vigência estimada de 20 anos e cuja finalidade primordial é mitigar até mesmo a exigibilidade das despesas primárias obrigatórias.

Assim, sairá de cena o contingenciamento preventivo feito no bojo do decreto de programação financeira, editado anualmente - em regra, até 30 dias após a publicação da LOA -, para que passe a viger um instrumento muito mais forte e antecipado de contenção das despesas primárias. Em todos os cenários, contudo, cabe reiterar a inexistência de qualquer iniciativa de aprimoramento equitativo das receitas, assim como acentuar uma vez mais a ausência de parâmetro de contenção das despesas financeiras, ou seja, as despesas decorrentes da gestão da dívida pública (amortização, rolagem e encargos).

Embora pretenda designar-se, no senso comum, como teto global para os gastos públicos, a bem da verdade, tal medida operará um ajuste fiscal seletivo e incompleto, na medida em que desconhece a necessidade de avançar na gestão mais equitativa e racional das receitas e no controle do avanço desarrazoado das despesas financeiras.

Agrava o cenário de iniquidade em comento o fato de a PEC do Teto assegurar tão somente correção monetária, a partir de 2018, para as aplicações mínimas em ações e serviços públicos de saúde, de que trata o art. 198, e em manutenção e desenvolvimento do ensino, prevista no art. 212, ambos os dispositivos da Constituição. A estagnação, em termos nominais, da despesa primária global da União e, sobretudo, dos deveres de gasto mínimo em saúde e educação contida nesse teto será tão mais destacada quanto maior for a expansão da arrecadação, em cenário de retomada da atividade econômica do país, ao longo dos 20 anos para os quais a PEC foi projetada.

Tais intervençôes graves e desproporcionais sobre a eficácia dos direitos fundamentais foram formalmente justificadas - em um primeiro momento por sua alegada transitoriedade e pela tentativa de mitigação "inevitável” de crises fiscais e econômicas ditas incontornáveis por outras vias. Quanto a isso, cabe o forte aviso de que ajuste fiscal algum se sustenta com a pura e simples discriminação entre despesas primárias e despesas financeiras, maldizendo aquelas independentemente do contraste com as respectivas fontes de custeio livres ou vinculadas e da repercussão das despesas financeiras para o equilíbrio global das contas públicas. Tampouco é admissível a mitigação dos pisos da saúde 
e da educação, em face das exceções estritamente discricionárias e aleatórias, por exemplo, do custeio das eleições e da capitalização de empresas estatais.

A via do ADCT e sua transitoriedade não podem simplesmente ferir de morte o texto permanente da Constituição. É preciso pensar o conflito distributivo que o orçamento público encerra em bases dramaticamente mais transparentes e mais resolutivas dos problemas eleitos legitimamente pela sociedade como prioridades estatais. Isso só é possível ampliando a conformidade do ciclo orçamentário com a Constituição de 1988, ao invés de impor uma rota abstrata de contingenciamento que nega a plena eficácia dos direitos fundamentais e posterga o debate para quando a reforma previdenciária se concretizar... 